\title{
Conceptual development of the transition from drill and blast excavation to non-blasting methods for the preparation of mined rock in surface mining UDC: $622: 271$ \\ DOI: $10.17794 /$ rgn.2019.3.3 \\ Original scientific paper
}

The Mining-Geology-Petroleum Engineering Bulletin

\author{
Boris Sobko'; Oleksii Lozhnikov'; Volodymyr Levytskyi²; Galyna Skyba² \\ ${ }^{1}$ Surface Mining Department, National Technical University Dnipro Polytechnic, Dmytro Yavornytsky av, 19, 49005, Dnipro, Ukraine \\ ${ }^{2}$ Faculty of Mining and Ecology, Zhytomyr State Technological University, str. Chudnivska 103, 10005, Zhytomyr, Ukraine
}

\begin{abstract}
This article is devoted to the conceptual development of the transition from drill and blast excavation to a non-blasting method for the preparation of hard rock before excavation at construction material deposits. The scientific and technical literature on the problems in the blasting of hard rock in preparation for excavation is analysed. A classification of mining equipment for the non-blasting development of a rock mass for excavation has been developed, taking into account the nature of the operation of mining equipment. The concept of the transition from drill and blast excavation to nonblasting methods in the preparation of mined rock in non-metallic material quarries is presented. The research results of the parameter determination of the elements of the system for the development of non-blasting equipment at a limestone quarry are presented. The economic efficiency of a hydraulic excavator with a ripper tooth for developing limestone with a strength of up to $30 \mathrm{MPa}$ is established.
\end{abstract}

Keywords:

non-blasting development, mechanical ripping, mining equipment, elements of the mining system, hard mined rocks

\section{Introduction}

The development of construction material deposits is one of the most important directions in surface mining, as the extraction of these minerals is essential for the construction, agricultural and chemical industries. To ensure a modern standard of living in developed countries, it is necessary to extract non-metallic materials at a rate of 12 to 14 tons per year per person.

In most cases, when developing mineral deposits of this group, the preparation of mined rock for excavation is carried out through drilling and blasting operations. The drilling and blasting preparation of the mined rock before the excavation has become the most widespread method in the practice of surface mining due to the simplicity of the process, its low cost, and high labor productivity. At the same time, there are a number of limitations related to the drilling and blasting excavation of mined rock, which can impede the carrying out of mining operations. Therefore, in recent decades, the direction of hard rock mechanical ripping has been actively developing. It makes it possible to reduce the volume of drilling and blasting operations, thereby expanding the application of surface mining and improving the ecological compatibility of mining.

As the world mining practice shows, the technology of the mechanical ripping of hard rock can be used at

Corresponding author: Volodymyr Levytskyi

v.levytskyi@ztu.edu.ua quarries while mining deposits of limestone, dolomite, gypsum, sandstone, chalk, marl, quartz and other minerals and overburden rocks with a strength within 20-90 $\mathrm{MPa}$. In some cases, harder rocks may be developed in case of increased fracturing, as well as reduced abrasiveness.

The transition from the drill and blast excavation of hard rock preparation to a mechanical method is possible in case of economic expediency, which can be achieved by reducing the number of mining processes, reducing the negative impact on the environment, and mining the deposits located within the sanitary protection zones and infrastructure facilities.

A great number of domestic and foreign researchers devote their works to the issues of non-blasting development and mechanical properties of rocks (Sobolevskyi, Korobiichuk et al., 2016; Sobolevskyi, Zuievska et al., 2016; Korobiichuk et al., 2018; Levytskyi et al., 2018). The results of studies on the expediency of using ripper bulldozers are presented in (Zou, 2017). In (Zou, 2017; Labutin et al., 2005; Fomin, 2013) the performance of mechanical shovels with pressure-enhanced soil is studied. The parameters of hydraulic shovels with a hydraulic hammer in the mining of hard rock minerals are investigated in (Lozhnikov, 2015; Kujundžić et al., 2008; Gill et al., 2006; Bilgin et al., 2002). These works (Imran, 2016; Schimm and Georg, 2015; Casteel, 2009) demonstrate the performance of milling combined machines. 
As a rule, the results given in the analyzed works describe the dependence of the performance of certain equipment types on the properties of rocks. At the same time, there are practically no works in which the questions of choosing a certain mining machine from the list of existing ones are considered on the basis of the physical and mechanical properties of the rocks, the performance of the equipment, or the required size fraction of the finished product. This is due to the fact that machinebuilding plants show their developments to the best advantage, but do not cover the problems of their application in specific fields. Therefore, the choice of effective equipment for the non-blasting development of mineral deposits with high rock strength remains an open question.

\section{Goals and objectives of research}

The aim of this research is the development of a methodological framework for the transition of technological schemes using drilling and blasting development of hard rock to non-blasting development. To achieve this goal, the following objectives were formulated and solved:

- establishing the urgency of the transition from drill and blast excavation to a non-blasting method of preparing the mined rock for excavation;

- analyzing the existing mining equipment for the non-blasting development of hard rock for excavation;

- developing a classification of mining equipment by the type of action for the non-blasting preparation of mined rock for excavation;

- developing the concept of the transition from drill and blast excavation to non-blasting methods of preparation of the mined hard rock in surface mining;

- carrying out research of technological parameters of the quarry during the transition from drill and blast excavation to a non-blasting method of preparing the mined rock for excavation.

\section{Analysis of existing mining equipment for the non-blasting preparation of hard rock for excavation}

The analysis of research works devoted to the equipment and technology of non-blasting development of hard rock showed that the general mining machines for the mechanical destruction are as follows: bulldozer ripper; mechanical shovel; hydraulic excavator with hydraulic hammer; hydraulic excavator with bucket replacement on the ripper tooth; hydraulic excavator; hydraulic excavator with rotary cutter; surface miner; and bucket wheel excavator.

Every machine has special working tools capable of crushing hard rock under high pressure. As a rule, these tools are already installed on the existing excavating and loading machines on the quarry. An exception is continuous-type machines, such as surface miners or bucket wheel excavators, which are manufactured specifically to take into account the physical and mechanical properties of each deposit and are not designed for the mining of rock.

\section{Classification of mining equipment for non-blasting mining of hard rock}

According to the technical characteristics of the previously mentioned machines, their classification was developed according to the strength of the rocks for uniaxial compression, the productivity of equipment, size fraction of the mined rock after crushing; and also the need for handling equipment and additional crushing was taken into account. A significant disadvantage in the operation of mining machines for the non-blasting development of mined rock is the loss of mineral due to regrinding. However, this disadvantage is also inherent in the drill and blast excavation of hard rock, so the question remains open concerning the permissible losses of the mineral from regrinding with the use of machinery for the nonblasting preparation of the mined rock for excavation.

Table 1 presents the classification of mining equipment by the type of the action for the non-blasting preparation of hard rock. Technical parameters of mining equipment were established according to analysis of scientific works and manufacturer's specifications. A continuous type of action implies that machines carry out the cutting and loading process at the same time. As we can see from the classification, the main range of rock hardness for uniaxial compression by machines for the mechanical crushing of hard rock is 20-100 MPa.

The productivity of these machines can vary from 20 to $3000 \mathrm{~m}^{3} / \mathrm{h}$. This is due to the different working tools of mining machines, as well as the physical and mechanical properties of hard rock in the massif of the quarry.

When offering the classification of mining equipment by the type of action for the non-blasting preparation of hard rock for excavation, the dependence of the productivity of mining machines on the rock strength was investigated. The highest productivity among machines for rock ripping was recorded for the surface miner and the ripper bulldozer when developing rocks with a strength of $20 \mathrm{MPa}$. At the same time, the lowest productivity was shown by the excavator with a tooth ripper, hydraulic hammer or rotary cutter (see Figure 1).

Analysis of the dependence of equipment productivity on rock strength, presented in Figure 1, allows for the drawing of the following conclusion: when using hydraulic excavators with attached equipment for ripping rocks, their productivity has a slight dependence on the rock strength in comparison with the surface miner and the bulldozer ripper. This is due to the low productivity of cyclic action equipment at the rocks ripping with different strengths, in comparison with continuous technol- 
Table 1 Classification of mining equipment for the non-blasting development of hard rock by the type of action

\begin{tabular}{|c|c|c|c|c|c|c|c|c|}
\hline $\begin{array}{l}\text { Type } \\
\text { of } \\
\text { action }\end{array}$ & Equipment type & $\begin{array}{c}\text { Strength } \\
\text { of rocks } \\
\text { on uniaxial } \\
\text { compression, } \\
\mathrm{MPa}\end{array}$ & $\begin{array}{l}\text { Productivity, } \\
\mathrm{m}^{3} / \mathrm{h}\end{array}$ & $\begin{array}{c}\text { Size } \\
\text { fraction, } \\
\mathrm{mm}\end{array}$ & $\begin{array}{l}\text { Excavating } \\
\text { equipment } \\
\text { requirement }\end{array}$ & $\begin{array}{l}\text { Transport } \\
\text { requirement }\end{array}$ & $\begin{array}{l}\text { Additional } \\
\text { crushing }\end{array}$ & $\begin{array}{l}\text { Loss from } \\
\text { regrinding, } \%\end{array}$ \\
\hline \multirow{6}{*}{ 尊 } & Dozer ripper & $50-80$ & $60-2600$ & $30-300$ & + &,+- &,+- & - \\
\hline & $\begin{array}{l}\text { Shovel with bucket } \\
\text { of active action }\end{array}$ & $60-100$ & $250-400$ & $30-400$ & - & + & + & - \\
\hline & $\begin{array}{l}\text { Excavator with } \\
\text { hydraulic hammer }\end{array}$ & $40-130$ & $30-250$ & $30-60$ & - & + & - & 2 \\
\hline & $\begin{array}{l}\text { Excavator with ripper } \\
\text { tooth }\end{array}$ & $80-150$ & $20-280$ & $30-300$ & - & + & - & 2 \\
\hline & Hydraulic excavator & $60-100$ & $400-850$ & $30-300$ & - & + & - & - \\
\hline & $\begin{array}{l}\text { Hydraulic excavator } \\
\text { with rotary cutter }\end{array}$ & $20-80$ & $80-200$ & $40-70$ & - & + & - & 30 \\
\hline \multirow{2}{*}{ 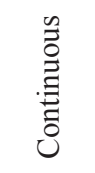 } & Surface miner & $40-120$ & $240-3000$ & $40-70$ & - & + & - & 30 \\
\hline & $\begin{array}{l}\text { Bucket wheel } \\
\text { excavator }\end{array}$ & $20-50$ & - & $20-40$ & - & + & - & - \\
\hline
\end{tabular}

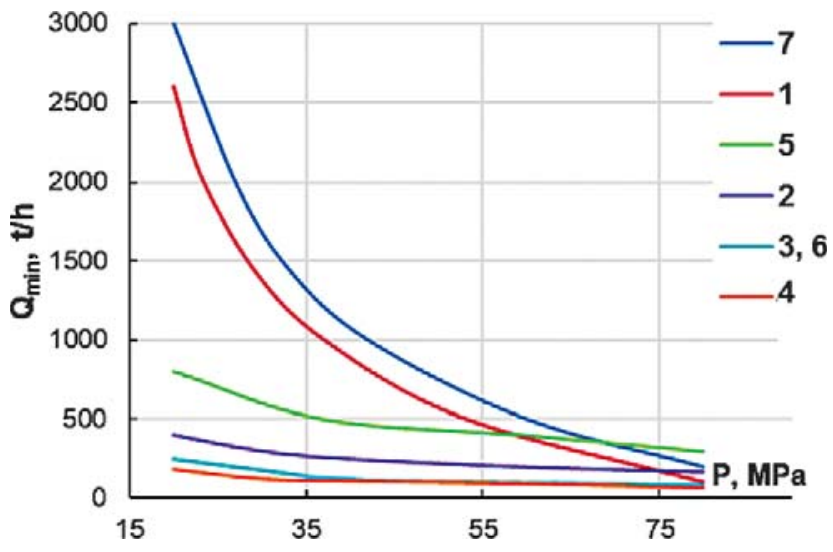

Figure 1: Dependence of the productivity of mining machines at the preparation for excavation on hard rock strength to uniaxial compression: 1 - bulldozer ripper, 2 - mechanical shovel of active action; 3 - hydraulic excavator with hydraulic hammer; 4 - hydraulic excavator with a ripper tooth; 5 - hydraulic excavator; 6 - hydraulic excavator with rotary cutter; 7 - surface miner

ogy. So, when the rock strength is increased from 20 to $80 \mathrm{MPa}$, for the cyclic action equipment, the productivity is reduced by 2 to 4 times, while for the continuous action equipment, it is reduced 6 to 10 times.

\section{Conceptual development of the transition from drill and blast excavation to non-blasting method of mined rock preparation in surface mining}

Modern methodological approaches to the selection of methods and equipment for mining process mechanization when preparing hard rock for excavation were formed in accordance with technical and economic calculations, which mainly took into account the factors of the effect of seismic waves on infrastructure objects and the development cost for the excavation of $1 \mathrm{~m}^{3}$ of mined rock. At the same time, mining and environmental factors that are relevant for drilling and blasting operations were not taken into account. These factors include: violation of the integrity of the rock massif and the land surface disturbance, changing the composition of ground water and surface water; soil contamination and degradation; formation of a dust and gas cloud; noise and vibration; emission of poisonous substances that pollute the environment; formation of lump rock; danger of working with explosives; the need to create and maintain the infrastructure necessary for the operation of equipment before and during drilling and blasting operations; the complexity of performing selective mining of minerals, etc.

As a result of the widespread use of drilling and blasting development in quarries of building materials, a fairly large amount of fine fractional waste (less than 20 $\mathrm{mm}$ ) of minerals has formed, the implementation of which is not cost-effective. This led to the fact that minerals, crushed in the process of drilling and blasting to small fractions, which are unmarketable, are stored in millions of tons in quarry dumps or temporary storage, diluted and converted into waste. Whereas, in addition to the loss of significant volumes of minerals, these dumps with small size fractions are sources of increased dusting, and have a negative impact on the environment.

The analysis of the condition of surface mining operations in quarries of construction materials showed that only a few mining enterprises converted to the mechanical development of hard rock, while the majority of quarries still use drilling and blasting operations to pre- 
pare hard rock as the only method option. This is primarily due to the lack of capital investments in the development of the mining equipment department of the quarry, and also because of the subjective opinion of mining engineers who consider the drill and blast excavation of the mined rock to be a cost-effective method. This statement has a basis in the case of direct comparison of the costs of drilling and blasting operations and mechanical development of hard rock. However, if we consider the technical and economic performance of the mining enterprise as a whole, then the effectiveness of the drilling and blasting development method will not be so obvious. This is explained by the fact that when the nonblasting preparation of rocks for excavation significantly reduces the volume of wasted mineral, in addition to making some auxiliary processes such as the drilling and crushing of oversized rock unnecessary, which is associated with a decrease in the volume of regrinding rock.

In general, the definition of an effective zone for the application of non-blasting methods of rock preparation for excavations in various quarries can be described using the proposed graph in Figure 2 which depicts the dependence of the mineral preparing cost on the strength of the rocks prepared using a non-blasting method instead of a drilling and blasting method for preparing hard rock.

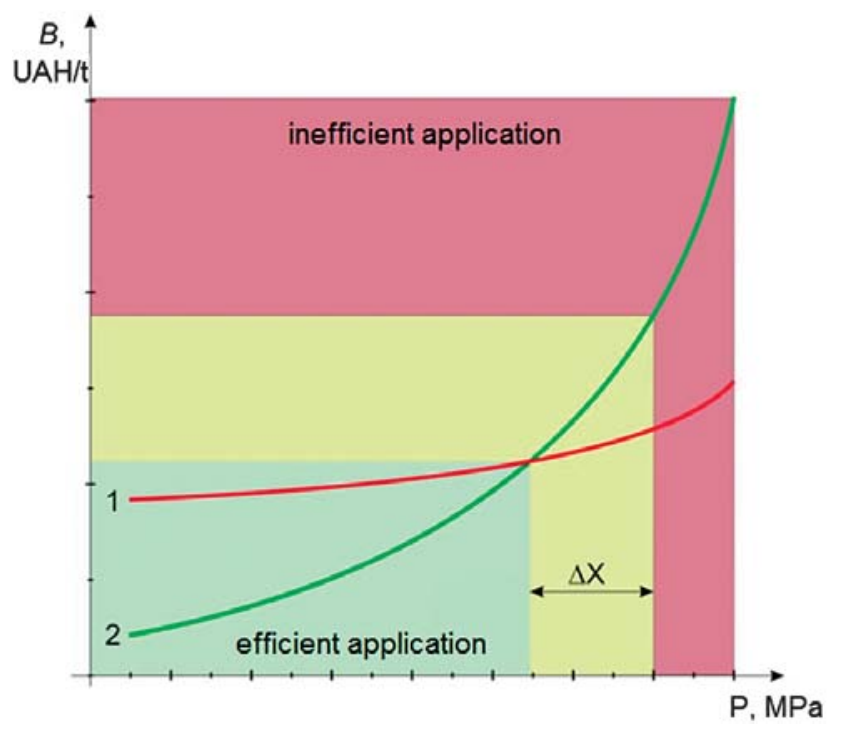

Figure 2: Dependence of the rock mining prime cost on their strength: 1 - using drilling and blasting preparation method; 2 - using mechanical ripping method

As can be seen from dependency diagrams shown in Figure 2, the prime cost of hard rock preparation with the use of drill and blast excavation has a weak dependence on their strength, while in the case of non-blasting operations, the dependence is more significant. The diagram indicates three zones of effectiveness of the application of the non-blasting preparation method. The first zone, highlighted in green, is typical for the case when the cost of mining of a mineral with a non-blasting preparation method is lower than during a drill and blast excavation. The second zone, marked in yellow, describes those cases from mining practice in which the use of explosive preparation of solid rock is more expensive than drilling and blasting. The blasting method is generally recommended except when we achieve a reduction in mining waste due to a decrease in the volume of small fraction sizes of the mineral; a reduction in the negative impact on the environment; a reduction in the area of sanitary protection zones, etc. The third zone, highlighted in red, shows that the use of non-blasting methods for preparation in this case is economically inexpedient and can be used only in the case of the development of minerals in sanitary protection zones where a restriction on the propagation of the seismic wave from drilling and blasting operations is established.

The most uncertain zone in terms of scientific research is the second, yellow zone. Since the effectiveness of the use of non-blasting preparation methods of hard rock is not obvious in this case, additional research is necessary. This research will prove the economic expediency of the transition from the drilling and blasting development of hard rock to mechanical.

When performing calculations to determine the economic feasibility of the transition from drill and blast excavation to non-blasting methods, the following factors should be taken into account:

1) a reduction in dust emissions;

2) noise reduction;

3) a reduction of vibration and seismic influence;

4) the absence of toxic gas emissions;

5) a reduction in the harmful impact on the state of the environment;

6) the possibility of extracting hard rock within the boundaries of populated areas;

7) in some cases, the possibility of avoiding the additional fragmentation of oversize;

8 ) a reduction in the waste of mineral resources due to an increase in volumes of marketable fractions;

9) simplification of mining;

10) the possibility of the selective mining of minerals;

11) a reduction in the number of open-pit mining operations (drilling, charging, blasting, milling).

The concept of the transition from a drilling and blasting to a non-blasting method for hard rock development is based on a comprehensive account of the improvement in the indices of the effects of surface mining on the environment (Gumenik et al., 2013). The result of such a transition should be an increase in the level of using environmentally-oriented resource-saving technologies for mining deposits, by reducing production waste and reducing emissions of harmful gases, noise and dust. Consequently, the use of non-blasting methods in the preparation of hard rock for excavation will give an additional economic and ecological effect. 


\section{Studies of the technological parameters of a quarry during the transition from drill and blast excavation to a non-blasting development method of mined rock}

The transition from a drill and blast excavation to a non-blasting development method of hard rock involves a change in the technological scheme of mining operations in a quarry. Elements such as the height of the bench, the width of the mine face, the width of the working area change greatly. This is due to the fact that when using the drilling and blasting development method, the height of the bench is selected within the range of 10-15 $\mathrm{m}$ to ensure the maximum performance of the excavators. Also, the height of the bench has a significant influence on the production of drilling and blasting operations, since the volume of rocks in a quarry after an explosion depends on it, and, consequently, the number of mass explosions per year.

The cut width is set based on the parameters of the excavation equipment operation within the range of 1.0$1.5 R_{c . r}$ (cutting radius). However, with a significant reduction in the bench height, which occurs with the use of non-blasting development methods, the width of the cut will also decrease to ensure efficient excavator performance. The width of the working area with the use of non-blasting methods will be significantly reduced, since there is no need to form significant areas for storing defragmented rock after drilling and blasting operations.

Each case of a non-blasting development method application in a separate quarry is individual and, as a rule, depends on the selected equipment for loosening and mining-and-geological conditions on the mineral deposit. The difference in the parameters of the mining system elements when using various ripping equipment is explained by the different design of the machine working tools and their impact on the rock mass.

When carrying out research on determining the changes in the parameters of the mining system elements of the quarry during the transition from drilling and blasting to a non-blasting method, a case from the practice of surface mining was considered. A hydraulic excavator with a bucket replacement for a tooth ripper was used as the equipment for the mechanical loosening of hard rock in a limestone quarry. The choice of this technological solution is based on the minimization of the capital investments that are required to purchase new mining equipment.

The quarry monitored for this research develops the West-Tyaginka limestone deposit. The mineral is represented by Pontian, Meotic and Upper Sarmatian limestones. The rock strength reaches up to $30 \mathrm{MPa}$, which allows for development using practically all the existing non-blasting methods. An essential drawback of the ap- plication of the drilling and blasting development of hard rock for excavation is the re-grinding of the mineral and an increase in the yield of small size fractions. These shortcomings have two negative effects. First, the output of large fractionality is reduced, which leads to a decrease in the profit of the enterprise. Secondly, the negative impact on the environment increases, as the non-marketable fraction accumulates in the dumps of the enterprise, after which the fine fraction is weathered.

In the transition from drilling and blasting to a nonblasting preparation method of mined rock, the parameters of the mining system elements have practically not even changed. In particular, the height of the bench, which is $3 \mathrm{~m}$, remained unchanged. However, the use of mechanical ripping under the conditions of this quarry required complex studies to select the rational thickness of the rock cutting layer. As the practice of surface mining shows, the thickness of the cutting layer has a significant effect on the performance of equipment for the mechanical loosening of hard rock.

The results of the research determining the dependence of the performance of the excavator with the ripper tooth on the strength and fracturing of rocks are shown in Figure 3. Studies have shown that the performance of an excavator when ripping rocks with a ripper tooth has a third degree dependence on the depth of the cut. At the same time, the indices differ during the development of highly fractured and medium fractured rocks. It is established that the maximum productivity of an excavator with a ripper tooth is achieved with a depth of cut chip thickness of $0.4 \mathrm{~m}$. At the same time, when working out weakly cracked rocks with a chip thickness of 0.2-0.4 m, the productivity is practically unchanged. With an increase in chip thickness greater than $0.4 \mathrm{~m}$, the productivity of the excavator at the development is reduced for rocks of any fracture.

The change in the technological scheme of the development of hard rock using a non-blasting method made it possible to increase the marketable size fraction output

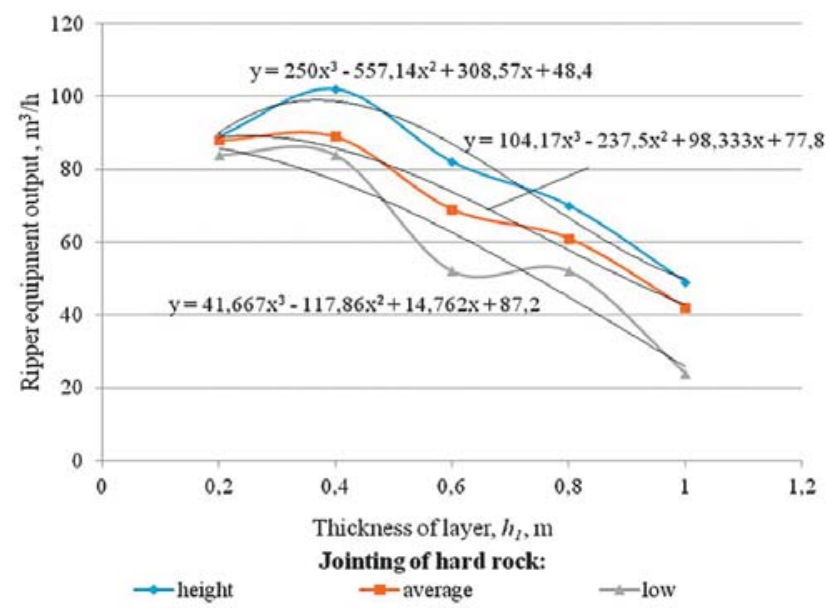

Figure 3: Dependence of performance of excavator with ripper tooth on the rocks strength and fracturing 
from the same volume of mineral due to a decrease in the volume of regrinding. Thus, the volume of the fraction $0-20 \mathrm{~mm}$ (waste materials) decreased by $33 \%$ from $60 \%$ to $40 \%$, due to an increase in the fraction $40-80$ $\mathrm{mm}$, which allowed for an increase in the annual productivity of the enterprise by 110 thousand tons. At the same time, the volume of the marketable fraction $20-40 \mathrm{~mm}$ remained unchanged.

The conducted studies made it possible to establish the efficiency of the transition from the drilling and blasting method of limestone development to the extraction and preparation using mechanical ripping by a hydraulic excavator with a ripper tooth. The economic efficiency of the use of a non-blasting technology for the development of hard rock is achieved by increasing the yield of commercial product and reducing the costs of preliminary rock breaking. Calculations of the economic performance of the mining company showed that the use of a non-blasting technology for the preparation of mined rock before excavation can reduce the cost of the mining and processing of limestone by $38 \%$.

\section{Discussion}

The obtained results confirmed the possibility of the concept of transitioning from drilling and blasting to non-blasting methods of hard rock preparation for excavation. The established dependencies of the mining equipment performance in the case of non-blasting preparation of the excavation of hard rock on its strength (see Figure 1) fully correspond to the findings obtained in the studies devoted to the determination of parameters of the bulldozer ripper (Zou, 2017), the mechanical shovel of the active action, hydraulic excavator with hydraulic hammer, hydraulic excavator with a ripper tooth, hydraulic excavator, hydraulic excavator with rotary cutter (Lozhnikov, 2015; Kujundžić et al., 2008; Gill et al., 2006; Bilgin et al., 2002) and surface miner (Imran, 2016; Schimm and Georg, 2015; Casteel, 2009). A common feature of all types of non-blasting mining equipment use is a decrease in productivity with an increase in rock strength. With rock strength more than 80 $\mathrm{MPa}$, the productivity dramatically decreases.

The determination of area of the effective application for non-blasting methods of hard rocks ripping in the pit, denoted in Figure 2, made it possible to identify three main cases for the transition from drilling and blasting to non-blasting technologies. One of the main criteria for the effectiveness evaluation of the use of non-blasting development methods is rock strength. Thus, with an increase in the strength of the rocks, the efficiency of using equipment for non-blasting development of the rocks decreases. In addition, the expediency of non-blasting methods decreases at low values of extracted minerals. This is completely confirmed by the results of earlier studies.
The obtained results, the established dependence of the performance of a hydraulic excavator with a ripper tooth on hard rock strength, compared with previous studies show that the theoretical results do not differ from practical ones. However, in contrast to the published findings in (Zou, 2017; Labutin et al., 2005), it was established that the jointing of a rock massif affects the performance of mining equipment. This dependence confirms that a decrease in the rock mass jointing also leads to a decrease in the performance of the ripper equipment. In addition, in contrast to the results in (Zou, 2017; Labutin et al., 2005), the findings of the current study established the effective depth of a cut. For limestone hardness of $30 \mathrm{MPa}$ the maximum performance of the hydraulic excavator with ripper tooth is reached when the depth of a cut is up to $0.4 \mathrm{~m}$. The obtained parameters make it possible to increase the efficiency of using mining equipment for the development of hard rock without drilling and blasting technology.

\section{Conclusions}

The current research confirmed the urgency of the transition from drilling and blasting to a non-blasting development method of hard rock, while excavating mining deposits of construction materials. The analysis of scientific and technical literature has shown that currently a considerable number of studies have been carried out in the field of non-blasting development of hard rock, however, they are usually devoted to individual types of equipment and don't compare existing mining equipment with each other, which makes it difficult to choose a certain type of machine for specific mining and geological conditions. A classification of mining equipment for the non-blasting preparation of mined rock for excavation has been developed, where the main criterion is the type of action of the equipment.

The concept of transitioning from a drilling and blasting method to the non-blasting preparation of mined rock is proposed, which takes into account not only the technical and economic performance of the enterprise, but also the influence of mining on the environment. The research established technological parameters of the quarry where a hydraulic excavator with a tooth ripper was used for limestone mining. The results of the research showed that using a hydraulic excavator with a ripper tooth to prepare limestone of strength up to 30 MPa for excavation instead of drilling and blasting operations allows for a reduction in cost by $38 \%$ on the mining and processing of limestone.

\section{References}

Bilgin, N., Dincer, T., Copur, H. (2002). The performance prediction of impact hammers from Schmidt hammer rebound values in Istanbul metro tunnel drivages. Tunnelling and 
Underground Space Technology, 17 (3), 237-247. https:// doi.org/10.1016/S0886-7798(02)00009-3

Casteel, K. (2009). German Equipment Suppliers Bet on Technology Though Times are Tough. Engineering and Mining Journal, 210(7), 42.

Fomin, S., Faul, A. (2013). Ways to reduce the environmental pressure on mining regions. Notes of the Mining Institute, 203.

Gill, H., Jones, M. D., Jones, D. I. E., Watson, J. L. (2006). Spon's Quarry Guide. To the British hard rock industry. CRC Press, 496.

Gumenik, I., Lozhnikov, A., \& Maevskiy, A. (2012). Methodological principles of negative opencast mining influence increasing due to steady development. Geomechanical Processes during Underground Mining: School of Underground Mining 2012, 45-49.

Imran, M. (2016). Variation of production with time, cutting tool and fuel consumption of surface miner 2200 SM 3.8. International Journal of Technical Research and Applications, 4 (1), 224-226.

Korobiichuk, V., Kravets, V., Sobolevskyi, R., Han, A., Vapnichna, V. (2018). Weakening of rock strength under the action of cyclic dynamic loads. Eastern-European Journal of Enterprise Technologies, 2/5 (92), 20-25. DOI: https:// doi.org/10.15587/1729-4061.2018.127847.

Kujundžić T., Bedeković G., Kuhinek D., Korman T., 2008, Impact of rock hardness on fragmentation by hydraulic hammer and crushing in jaw crusher, The Mining-Geological-Petroleum Engineering Bulletin, 20 (1), 83 - 90

Labutin, V., Matthis, A., Zaitseva, A. (2005). Explosive development of coal seams by excavators with a bucket of active action. Physico-technical problems of mining of mineral resources, 2, 59-66.

Levytskyi, V., Sobolevskyi, R., Korobiichuk, V. (2018). The optimization of technological mining parameters in a quarry for dimension stone blocks quality improvement based on photogrammetric techniques of measurement. Rudarsko-geološko-naftni zbornik, 33 (2), 83-90. DOI: https:// doi.org/10.17794/rgn.2018.2.8.

Schimm, B., Georg, J. (2015). Wirtgen Surface Miner-The First Link of a Simple Extraction and Materials Handling Chain in "Medium Hard"- Rock. In Proceedings of the 12th International Symposium Continuous Surface Mining-Aachen 2014, Springer, Cham, 511-515. DOI https:// doi.org/10.1007/978-3-319-12301-1_44.

Gumenik, I.L., Lozhnikov, O.V., Panasenko, A.I. (2013). Deliberate dumping technology for mining reclamation effectiveness improvement. Scientific Bulletin of National Mining University, (5), 48-53.

Sobolevskyi, R., Korobiichuk, V., Iskov, S., Pavliuk, I., Kryvoruchko, A. (2016). Exploring the efficiency of applying fractal analysis for the process of decorative stone quality control. Eastern-European Journal of Enterprise Technologies, 6/3 (84), 32-40. DOI: https://doi.org/10.15587/17294061.2016 .85227$.

Sobolevskyi, R., Levytskyi, V., Shlapak, V. (2016). Evaluation of accuracy of photogrammetric methods and laser scanning for measuring of parameters of cracks natural separateness. The Journal of Zhytomyr State Technological University. Series: Engineering, 1 (76), 158-164.

Pavlychenko, A., \& Kovalenko, A. (2013). The investigation of rock dumps influence to the levels of heavy metals contamination of soil. Mining of Mineral Deposits, 237-238.

Sobolevskyi, R., Zuievska, N., Korobiichuk, V., Tolkach, O., Kotenko, V. (2016). Cluster analysis of fracturing in the deposits of decorative stone for the optimization of the process of quality control of block raw material. EasternEuropean Journal of Enterprise Technologies, 5/3 (83), 2129. DOI: https://doi.org/10.15587/1729-4061.2016.80652.

Zou, Dingxiang (2017). Non-blasting Excavation. Theory and Technology of Rock Excavation for Civil Engineering. Springer, Singapore, 269-283. 


\section{SAŽETAK}

\section{Konceptualni razvoj prijelaza iz metoda bušenja i miniranja eksplozivom u metode bez miniranja za eksploataciju stijena u površinskome rudarstvu}

Članak je posvećen konceptualnomu razvoju prijelaza iz metoda bušenja i miniranja eksplozivom u metode bez miniranja pri obradi stijene prije iskapanja na nalazištima građevinskih materijala. Analizira se znanstvena i tehnička literatura posvećena problemima miniranja eksplozivom stijene za iskop. Razvijena je klasifikacija rudarske opreme za obradu stijenske mase bez razaranja do iskopa koja uzima u obzir način rada rudarske opreme. Prikazana je koncepcija prijelaza iz metoda bušenja i eksplozije u metode bez miniranja stijena u kamenolomima nemetalnih sirovina. Prikazani su rezultati istraživanja utvrđivanja parametara elemenata sustava za razvoj opreme bez miniranja u kamenolomu vapnenca. Utvrđena je ekonomska učinkovitost hidrauličnoga bagera sa zupčastim nastavkom za izradu vapnenca čvrstoće do 30 MPa.

\section{Ključne riječi:}

razvoj neminiranja, mehaničko usitnjavanje, rudarska oprema, elementi rudarskoga sustava, tvrde minirane stijene

\section{Authors contribution}

Boris Sobko: leader of the field investigations on all presented localities; analysed, synthesized and interpreted field and laboratory data; wrote most of the text of the article. Oleksii Lozhnikov: participated in field investigations on all localities, providing guidelines for the manuscript. Volodymyr Levytskyi: collected data and analysed them for selection in this publication. Galyna Skyba: analysed them for selection in this publication. 